UDC 339.138:[658.87:004.738.5(477)]

JEL Classification: C 1, L 81, M 31

Alona O. Natorina

PhD (Economics), Head of the Higher Education Statistics and Analysis Department SSI "Institute of Educational Analytics"

(Kyiv, Ukraine)

\title{
QUALITATIVE ASSESSMENT OF MARKETING FACTORS THAT INFLUENCE DIGITAL BUSINESS
}

The private immanent components of qualitative measurement that influence online retailers management system of marketing commodity policy (MSMCP) are systematized and the architectonics is developed. The latent root causes of the online retailers' MSMCP formation that determine the private immanent components of qualitative measurement and explain the correlation between the relevant features and their meaningful interpretation are identified. The canonical models for assessing the private immanent components of qualitative measurement that influence online retailers' MSMCP are developed. The realization of the models is the foundation for generating effective marketing decisions and the achievement of relevant goals through a single managerial impact. The methodical approach to the qualitative assessment marketing factors that influence digital business is justified. The proposals and recommendations for online retailers are developed based on the results of the methodical approach test and validation.

Key words: digital business, online retailer, management system of marketing commodity policy, immanent component, canonical model.

\section{DOI: 10.15276/mdt.3.1.2019.7}

Statement of the problem in general form and it's connection with important scientific or practical tasks. The rapid digital business development in recent years in Ukraine proves its effectiveness. In conditions of high market competition, the digital business is able to quickly respond to changes in a changing marketing environment, as well as adapt its own business processes. Considering the above, the relevance of the justification and implementation of approaches that contribute to the effective management of digital business are increasing.

Analysis of the latest research and publications, which initiated the solution of this problem and on which the author relies. Ukrainian and foreign scientists and economists have researched different aspects of the digital business conduct and development in a changing marketing environment. In the work by Cabolis C. ("The World Digital Competitiveness Ranking", 2017) and the monograph by Oklander M., Oklander T. and Yashkina O. ("Tsyfrovyi marketynh - model marketynhu XXI storichchia", 2017) the authors revealed the features of digital marketing usage and the development of a digital business model in a digital business transformation. The benefits of business digitalization and characteristics of drives digital transformation are justified in study by Kane G., Palmer D., Philips Nguyen A., Kiron D. and Buckley N. (“Strategy, Not Technology, Drives Digital Transformation”, 2015).

(C) 2019 The Authors. This is an open access article under the CC BY license (http://creativecommons.org/licenses/by/4.0/) 
Bharadwaj A., El Sawy O., Pavlou P. and Venkatraman N. ("Digital business strategy: toward a next generation of insights", 2013) described in detail the business processes digitalization, the use of relevant marketing tools for the development of digital business, as well as rapid adaptation to changing environmental conditions.

Despite the significant amount of studies about digital business, it remains relevant to regard the assessment of the marketing environment for the digital business. Today, there is no universal methodology for assessing marketing factors that influence digital business.

Formulation of the purpose of the article (statement of the problem). The purposes of the articles are to justify the methodical approach to the qualitative assessment marketing factors that influence the digital business and test this approach on online retailers; to develop proposals and recommendations for online retailers based on the results of methodical approach validation.

Statement of the main material of the research with full justification of the scientific results obtained. Today, digital business is one of the important parts of the Ukrainian economy in the context of ensuring its sustainable development. Marketing commodity policy is the determinant of successful digital business. The issue of marketing commodity policy realization can be solved only taking into account the effective functioning of management system of marketing commodity policy (MSMCP). The online retailers' MSMCP is affected by a combination of private immanent components of qualitative and quantitative measurement. In this study, an appropriate approach to the assessment of the private immanent components of qualitative measurement that influence online retailers' MSMCP are justified taking into account its complexity when applied in practice.

The Figure 1 represents the architectonics of the private immanent components of qualitative measurement that influence online retailers' MSMCP.

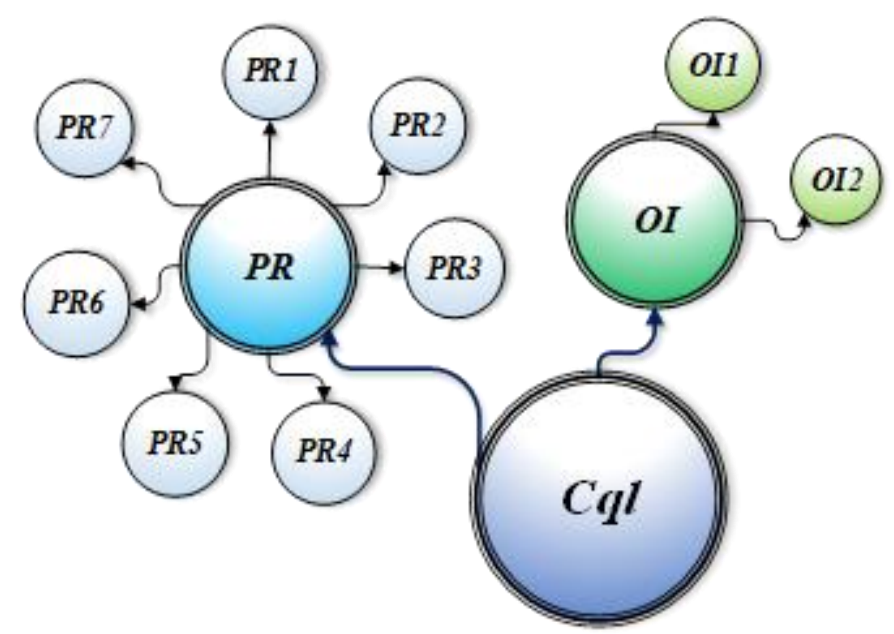

Notes: $C q l$ - the private immanent components that influence online retailers' MSMCP (qualitative measurement); $P R$ - the product range competitiveness; $P R I$ - the rhythm of the goods sale; $P R 2$ - the rationalization of the product range; $P R 3$ - the level of product range update; $P R 4$ - the product range harmony; $P R 5$ - the product range sustainability; $P R 6$ - the level of marketing elements usage in the product range formation; $P R 7$ - the degree of integration with the product category management system; $O I$ - the interaction with online shoppers; $O I 1$ - the loyalty level of online shoppers; OI2 - the degree of online shoppers needs satisfaction.

Figure 1 - The architectonics of the private immanent components of qualitative measurement that influence online retailers' MSMCP

Source: developed by the author 


$$
\begin{gathered}
\text { According to } \quad \text { the } \\
P R=\{P R 1 ; P R 2 ; P R 3 ; P R 4 ; P R 5 ; P R 6 ; P R 7\} \text { and } O I=\{O I 1 ; O I 2\} .
\end{gathered}
$$

It is the first immanent component of qualitative measurement that affects MSMCP. The seven latent root causes of MSMCP formation determine this component.

1. The rhythm of the goods sale (PR1).

The rhythm of the goods sale is a latent root cause, because it allows to provide the timely receipt of the required amount of goods to online shoppers. It affects the online retailer's online shopping revenue. The low rhythm level leads to the loss of planned profit, which complicates the financial position of the online retailer and contributes to the emergence or growth of accounts payable. Therefore, the development of measures to prevent disruption of the rhythm of the goods sale is one of the main tasks in the framework of the stable operation of the online retailer and its sustainable development. Thus, the adjustment of the online retailer's activity is carried out to ensure the rhythm of the goods sale, as well as to identify and eliminate the possible causes of a drop in the level of rhythm.

2 . The rationalization of the product range $(P R 2)$.

This is the latent root cause of the MSMCP formation, which reflects the concentration of efforts in market segments. According to the monitoring results of the demand for assortment positions, the online retailer makes decision about the implementation of further marketing commodity policy, including the rationalization of the product range.

3. The level of product range update (PR3).

It is possible to get competitive information about the market, online retailer, behavior and tartget audience needs. It is advisable for online retailers to use this knowledge to distinguish themselves from the competition in terms of digitalization, given the positive experience and the experience of online shoppers, that depends on the level of renovation product range. This indicates the direct impact of the level of product range update on the MSMCP formation and confirms the expediency of considering the indicator as a latent root cause.

4. The product range harmony (PR4).

This is the latent root cause of the MSMCP formation, which characterizes the degree of proximity between the goods of different product groups in terms of their intended use, requirements for the organization of distribution marketing channels of online retailers. The biggest group harmony different assortment with more types of goods, and the smallest harmony - a mixed assortment.

5 . The product range sustainability $(P R 5)$.

This is the latent root cause of the formation of MSMCP, which demonstrates the ability of the product range of online retailers to meet the demand for the same commodity positions, which feature strong demand. However, if there is a universal value of the stability coefficient of the product range for retailers that carry out traditional activities, the value of this coefficient is not universal for online retailers. Therefore, in practice it is determined by the results of using the method of expert assessments.

6 . The level of marketing elements usage in the product range formation (PR6).

During formation of the product range in the Internet and for finding and attracting online shoppers, online retailers determine online marketing elements and the corresponding elements necessary for use in their own activities, based on the developed portrait of potential online shopper.

7. The degree of integration with the product category management system (PR7).

This is a latent root cause, which demonstrates the ability of online retailers to respond quickly and promptly to the actions of competitors operating in a dynamic market with a high 
degree of uncertainty in the external environment, which, in particular, requires an appropriate level of integration with the product category management system.

Below are two latent root causes that determine the interaction of online retailers with online shoppers (OI), as the second private immanent component of qualitative measurement that influence online retailers' MSMCP.

1. The loyalty level of online shoppers $(O I 1)$.

The loyalty and positive experience of online shoppers to certain product positions in the online retailer product range is a prerequisite for increasing the number of regular online shoppers. That is why the loyalty level of online shoppers is one of the latent root causes.

2. The degree of online shoppers needs satisfaction (OI2).

This is a latent root cause, which demonstrates the online retailer ability to satisfy the varied demands and preferences of online shoppers. Indicator of the degree of online shoppers needs satisfaction can be the availability of online shoppers' reviews on the online retailer's website. The combination of positive reviews and negative ones allows online retailers to increase the level of trust of online shoppers.

Thus, according to the British agency Reevoo (2018), the presence of a certain percentage of negative reviews has a positive effect on site conversion. Online shoppers read the negative reviews and pay more attention to this web pages with goods. It increases the likelihood of purchase. Online shoppers trust more that online retailer on which web pages they see positive and negative ratings, and their absence causes suspicion and mistrust. Therefore, a significant amount of positive feedback is one of the main criteria that an online shopper uses when making an online order. That is why online shoppers' reviews are an important component of the online retailer's activity and at the same time a latent root cause.

Reviews help an online shopper to make the final choice of goods from several alternatives. According to a study of experts in the online commerce (The World Economic Forum, 2018):

$-63 \%$ of online shoppers in a stable market environment will quickly make a purchase in the online shop, which has reviews than in the one on whose pages they are not;

$-86 \%$ of online shoppers claim to rely on reviews from other online shoppers as well as personal recommendations;

- availability of reviews of the product catalog offers ensures the growth of online sales at about $18 \%$.

In addition, online shoppers' reviews have a number of other advantages for online retailers, in particular, the positive impact on search engine rankings.

In this context, the advantages of having feedback from online shoppers will be as follows (Prom.ua, 2017):

1) additional unique content - product descriptions usually contain descriptions from producers that are not unique and are duplicated on various websites, so online shoppers' reviews are a way to increase the amount of unique content on such pages and improve their ranking in search results;

2) the growth of transitions on low-frequency queries, namely, these are "product name" + "review / feedback" type requests, which are especially popular in a certain niche; the availability of such information on the online retailer's website has a positive effect on the growth of search traffic for the above requests;

3) product rating in the online search. It is the rating from the product page, which is displayed using the micro markup and in the search results, increases the click-through rate in the search results, the number of transitions of potential online shoppers and ranking in general. This rating is based on the evaluation of goods by online shoppers. 
The methodical approach for the assessment was tested on Ukrainian online retailers. According to the results of analytical studies at the international and national levels (All Retail, 2018; GfK Ukraine, 2018; KPMG, 2018; Ukrainian Retail Association, 2018), it was found that the set of Ukrainian online retailers can be divided into seven segments, depending on their field of activity and specialization: DIY-retailers (construction, furniture and household retailers); drogeries; pharmacy retailers; food retailers; retailers in the field of household appliances and electronics; fashion retailers; retailers in other areas. Considering the activity of online retailers in the Internet, it was identified the largest Ukraine online retailers (21) in 2018 in four market segments, among which food retail, drogeries, retail in household appliances and electronics, DIY-retail.

As part of the study, the necessary calculations were carried out in the demo versions of the software packages "SPSS Statistics" and "STATISTICA". This formed the basis for the canonical models development, and the assessment of the private immanent components influence on MSMCP.

The latent root causes were identified as a first step of this study and the models for assessing the private immanent components of qualitative measurement that influence online retailers' MSMCP were developed. The methodical approach, applied in assessing the influence of private immanent components of qualitative measurement that influence online retailers' $\operatorname{MSMCP}(P R, O I)$, is to find the average scores of evaluations of experts in Ukraine online commerce. To determine the consistency of expert answers, the mathematical tools were used, namely - the Spearman's rank correlation coefficient and the concordance coefficient.

So, to determine the degree of consistency of expert opinions about assessment of latent root causes of the MSMCP formation, the coefficient of concordance was calculated by the formula (1) (according to Matskul, V.M., 2016):

$$
K_{c o n}=\frac{\sum_{j=1}^{n} d_{j}^{2}}{\frac{1}{12}\left[m^{2}\left(n^{3}-n\right)-m \sum_{i=1}^{m} T_{i}\right]}
$$

where $K_{c o n}$ - the coefficient of concordance, $n$ - the number of factors, $m$ - the number of experts, $T_{i}$ - the results of intermediate calculations (2), $d_{j}$ - the deviation of the amount from the average sum of ranks (3) (Matskul, V.M., 2016):

$$
\begin{gathered}
T_{i}=\sum_{l=1}^{L}\left(t_{e}^{3}-t_{e}\right), \\
d_{j}=S_{j}-\frac{\sum_{j=1}^{n} S_{j}}{n},
\end{gathered}
$$

where $L-$ the number of groups of related (identical) ranks in the ranking, $t_{e}-$ the number of related ranks in each group, $S_{j}$ - sum of ranks, intended by experts $j$ (4) (Matskul, V.M., 2016): 


$$
S_{j}=\sum_{i=1}^{m} R_{i j}
$$

The second step is to determine the significance of the estimates of indicators. Based on the use of the demo version of the "SPSS Statistics" software package, the calculations were automated and the concordance coefficients $\left(K_{c o n}\right)$ for two latent root causes were calculated. They are defined so that they are significant, and the consistency of expert assessments is satisfactory.

Based on the fact that $K_{c o n}$, thus obtained, is a random variable, its reliability was investigated, i.e., the statistical significance of the coefficient of concordance was checked. The assessment of the significance of the coefficients carried out by the Pearson criterion $\left(\chi^{2}\right)$. $K_{c o n}$ in the presence of connected ranks with $v=n-1$ degrees of freedom has $\chi^{2}-$ distribution (5) (Matskul, V.M., 2016):

$$
\chi^{2}=\frac{\sum_{j=1}^{n} d^{2}}{\frac{1}{12}\left[m n(n+1)-\frac{1}{n-1} \sum_{i=1}^{m} T_{i}\right]}
$$

According to the results of the calculations, it was found that $\chi^{2}$ for two latent root causes there is more than a tabular $\chi_{t}^{2}$ subject to a confidence level of 0.95 , so it is the evidence of the coincidence of expert opinions.

The Table 1 demonstrates the general results of the canonical analysis of the private immanent components of qualitative measurement that influence online retailers' MSMCP (based on the results in "STATISTICA"). According to the Table 1 shows, $\mathrm{R}=0.894$ which indicates a strong relationship between the groups of variables. $\chi^{2}$ equals 32.953 at the level $\mathrm{p}$ less than 0.005 indicate the significance of the canonical correlation.

\begin{tabular}{|c|c|c|}
\hline \multicolumn{3}{|c|}{ Canonical $R=0.739 \quad \chi^{2}(15)=20.618 p=0.004$} \\
\hline & Left set & Right set \\
\hline No. of vars. & 5 & 3 \\
\hline Variance extracted & $81,035 \%$ & $100,000 \%$ \\
\hline Total redundancy & $18,979 \%$ & $43,121 \%$ \\
\hline Variables: & TS1 & $C P 1$ \\
\hline 2 & $T S 2$ & $C P 2$ \\
\hline 3 & $T S 3$ & CP3 \\
\hline 4 & TS4 & \\
\hline 5 & TS5 & \\
\hline
\end{tabular}

Table 1 - The general results of the canonical analysis

Source: calculated by the author 
As can be seen from the Table 1, the left set is formed by 7 variables, and the right - by 2. The dispersion of the left set is $69.125 \%$, and the right one is $100.000 \%$. In the left set, $42.032 \%$ of the variables are explained by the right set, and in the right, $74.673 \%$ of the variables are explained by the left set. Under each set are listed variables that are included there. The values of the canonical roots, as determined by the results of canonical analysis, are shown in the Table 2.

Table 2 - Values of the canonical roots

\begin{tabular}{|c|c|c|}
\hline Parameter & Root 1 & Root 2 \\
\hline Value & 0.786 & 0.481 \\
\hline
\end{tabular}

Source: calculated by the author

It should be noted that the number of canonical roots is equal to the number of variables in a smaller plural number. In our case, the number of canonical roots equal 2 . When calculating the roots, all maximally correlated weighted amounts are considered to define the canonical root as the "designation" of latent root causes. The Figure 2 shows the fall in eigenvalues of canonical roots, which confirms the results, which also the Table 2 shows.

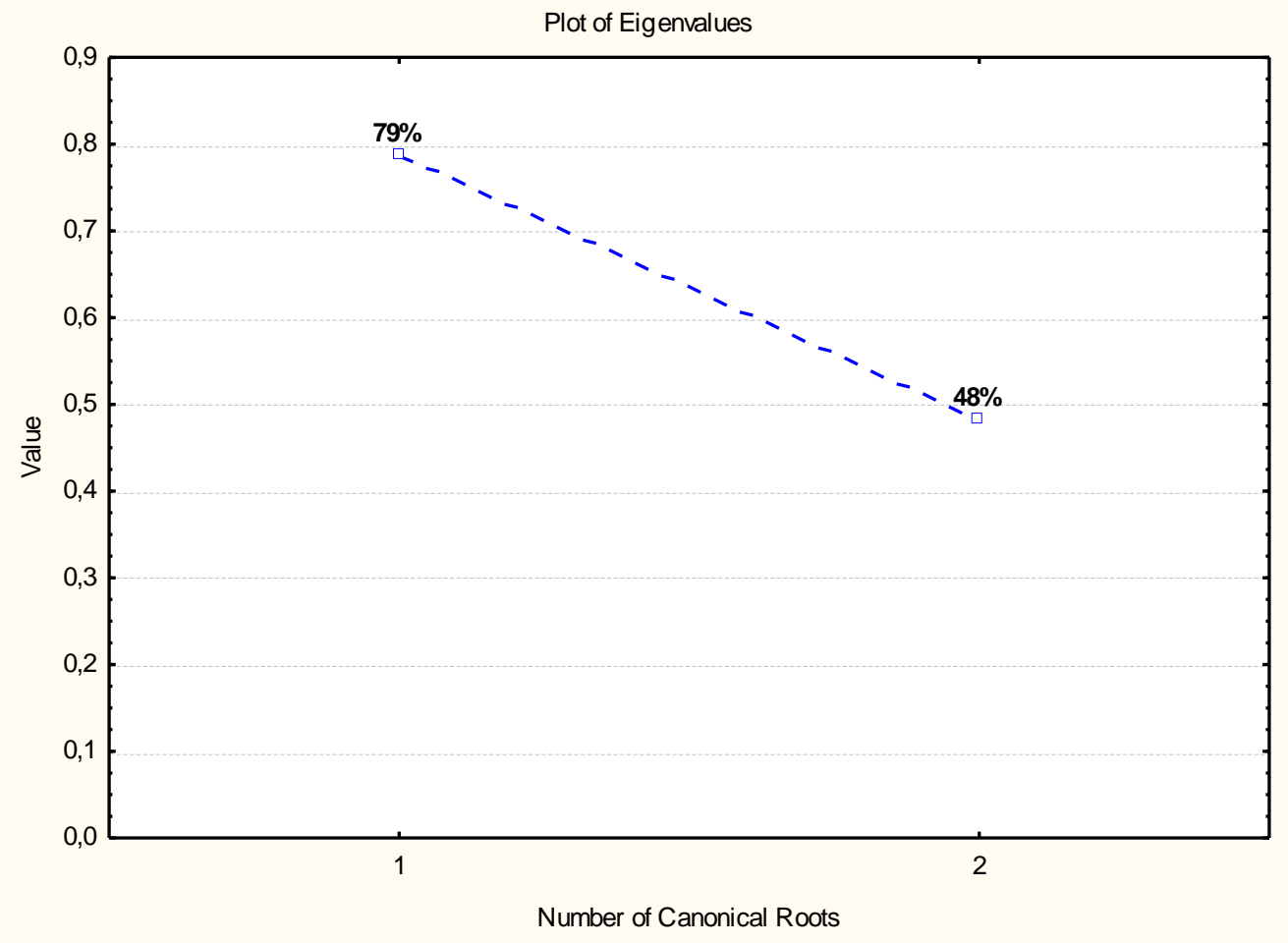

Figure 2 - The Graphic of canonical roots values

Source: developed by the author

To check the significance of all canonical roots, $\chi^{2}$-statistics are defined for each of them. The $\chi^{2}$-test results are given in the Table 3 . 
Table $3-\chi^{2}$-test results

\begin{tabular}{|c|c|c|c|c|c|c|}
\hline Root & Canonical $\boldsymbol{R}$ & Canonical $\boldsymbol{R}$-sqr. & $\chi^{2}$ & $\boldsymbol{v}$ & $\boldsymbol{P}$ & $\lambda$ \\
\hline 0 & 0.887 & 0.786 & 32.953 & 14 & 0.003 & 0.111 \\
\hline 1 & 0.693 & 0.481 & 9.830 & 6 & 0.132 & 0.519 \\
\hline
\end{tabular}

Source: calculated by the author

According to the results of the Table 3, canonical roots should be considered statistically significant in order to use them for further calculations. The load of canonical factors (structural factors) are given in the Tables 4-5. In the left set, the first root is determined by PR5 (product range sustainability), and the right root is defined by $P R 2$ (rationalization of the product range), that equal to -0.773 and 0.788 respectively (Table 4 ).

Table 4 - The factor structure of the left set

\begin{tabular}{|c|c|c|}
\hline Parameter & Root 1 & Root 2 \\
\hline$P R 1$ & -0.422 & 0.675 \\
\hline$P R 2$ & -0.415 & 0.788 \\
\hline$P R 3$ & -0.597 & 0.763 \\
\hline$P R 4$ & -0.485 & 0.484 \\
\hline$P R 5$ & -0.773 & 0.466 \\
\hline$P R 6$ & -0.567 & 0.341 \\
\hline$P R 7$ & -0.396 & 0.770 \\
\hline
\end{tabular}

Source: calculated by the author

For the right set (Table 5), the first root is determined by OII (loyalty level of online shoppers) and it equals to -0.965 , and the second root is determined by $O I 2$ (degree of online shoppers needs satisfaction) and it equals to 0.433 .

Table 5 - The factor structure of the right set

\begin{tabular}{|c|c|c|}
\hline Parameter & Root 1 & Root 2 \\
\hline OI1 & -0.965 & -0.263 \\
\hline OI2 & -0.901 & 0.433 \\
\hline
\end{tabular}

Source: calculated by the author

The Table 6, that placed below in the text, shows the dispersions of the left and right sets.

Table 6 - The dispersions of the left and right sets

\begin{tabular}{|c|c|c|c|c|}
\hline \multirow{2}{*}{ Parameter } & \multicolumn{2}{|c|}{ Left set } & \multicolumn{2}{c|}{ Right set } \\
\cline { 2 - 5 } & $\begin{array}{c}\text { Variance } \\
\text { extracted }\end{array}$ & Redundancy & $\begin{array}{c}\text { Variance } \\
\text { extracted }\end{array}$ & Redundancy \\
\hline Root 1 & 0.288 & 0.227 & 0.872 & 0.685 \\
\hline Root 2 & 0.403 & 0.194 & 0.128 & 0.062 \\
\hline
\end{tabular}

Source: calculated by the author 
The dispersions in the Table 6 can be characterized as average, which is explained by the corresponding roots. So, in the left set the second root explains $40.3 \%$ of the variance, and the first root is $28.8 \%$. The right set of first root explains $87.2 \%$ variance, and the second $12.8 \%$. In addition, according to the results of canonical analysis, canonical weights for each set of variables are determined (Tables 7-8). Weights can be used to interpret canonical roots. The larger the absolute weight, the greater the contribution of the corresponding variable in the canonical variable value.

The Table 7 shows that, for the right set, the largest contribution to the weight of the first canonical variable is made by the $O I I$ (loyalty level of online shoppers), which equals to 0.661 . The largest contribution to the weight of the second canonical variable is OI2 (degree of online shoppers needs satisfaction), that equals to -0.402 .

Table 7 - The canonical weights for the right set

\begin{tabular}{|c|c|c|}
\hline Parameter & Root 1 & Root 2 \\
\hline OI1 & -0.661 & -0.376 \\
\hline OI2 & -0.402 & 0.372 \\
\hline
\end{tabular}

Source: calculated by the author

For the left set, the largest contribution to the weight of the first canonical variable is made by the $P R 5$ (product range sustainability). It equals to 0.979 . For the right set, the largest contribution to the weight is made by the $P R 7$ (degree of integration with the product category management system). It equals to 0.932 (Table 8).

Table 8 - The canonical weights for the left set

\begin{tabular}{|c|c|c|}
\hline Parameter & Root 1 & Root 2 \\
\hline$P R 1$ & -0.269 & -0.431 \\
\hline$P R 2$ & 0.775 & 0.806 \\
\hline$P R 3$ & -0.756 & 0.317 \\
\hline$P R 4$ & 0.048 & 0.258 \\
\hline$P R 5$ & -0.779 & -0.551 \\
\hline$P R 6$ & -0.688 & -0.826 \\
\hline$P R 7$ & 0.279 & 0.932 \\
\hline
\end{tabular}

Source: calculated by the author

The canonical weights can be interpreted as factor loadings, so it can be argued that at the first canonical root $O I 1$ (loyalty level of online shoppers) is on the negative pole, and PR5 (product range sustainability) is on the positive pole. At the second canonical root $O I 2$ (degree of online shoppers needs satisfaction) and $P R 7$ (degree of integration with the product category management system) are on the positive pole.

The Figure 3 shows a graphic interpretation of the relationship between canonical variables from the right and left sets. 


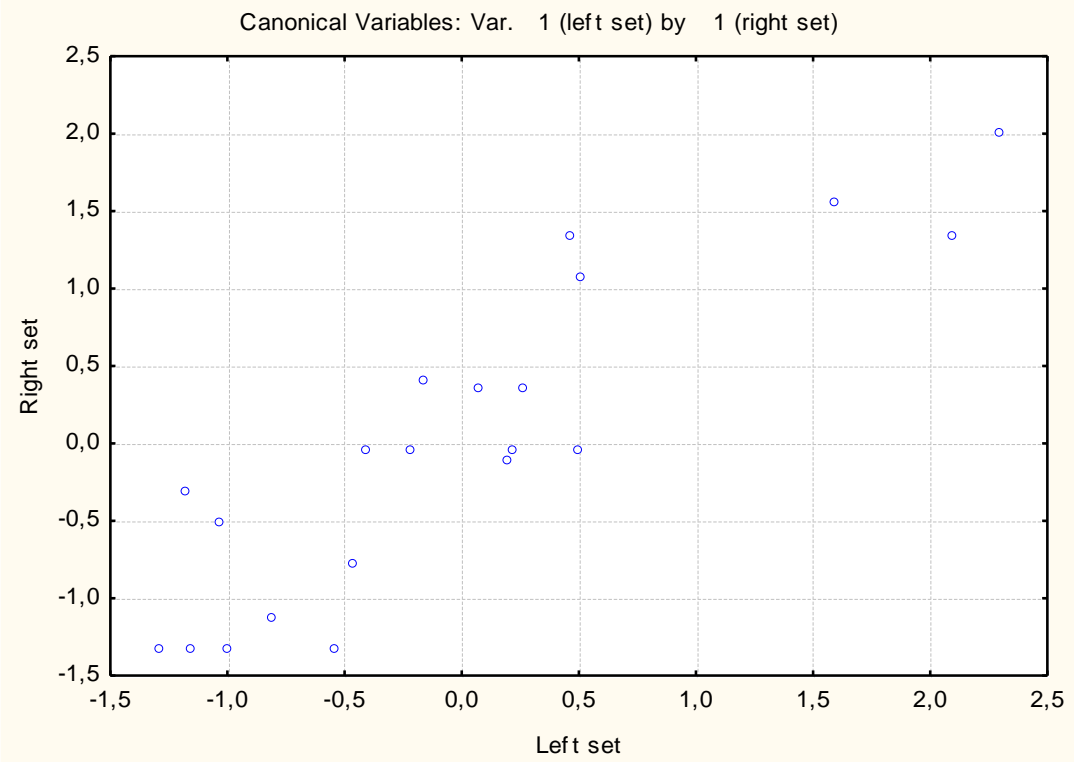

Figure 3 - Scatterplot of canonical variables

Source: developed by the author

In the Figure 3, there are no pronounced outliers. In addition, deviations from the regression line do not form any characteristic outlines (for example, being located in the form of $U$ or $S$ around the regression line). Therefore, it can be concluded that no significant violations of the fundamental assumptions of the canonical analysis are not observed. The Figure 3 clearly reflects the division of observations into specific groups (clusters). It shows that the sample of 21 online retailers under consideration is heterogeneous.

To develop a mathematical models for assessing the influence of private immanent components of qualitative measurement that influence online retailers' MSMCP, the canonical weights for the left and right sets were used. The obtained canonical models for assessing the traffic statistics $Z_{P R}(6)$ and filling the commodity portfolio $Z_{O I}$ (7) are given below:

$$
\begin{gathered}
Z_{P R}=\mid 0.431 P R 1+0.806 P R 2-0.756 P R 3+ \\
+0.258 P R 4-0.779 P R 5-0.826 P R 6+0.932 P R 7 \mid \\
Z_{O I}=|-0.661 O I 1-0.402 O I 2|
\end{gathered}
$$

To assess the private immanent components of qualitative measurement that influence online retailers' MSMCP, namely, the product range competitiveness and the interaction with online shoppers, in the canonical assessment models $Z_{P R}$ and $Z_{O I}$, the value of the PRI-PR7 and $O I 1-O I 2$ were set as latent root causes. The results of calculations are shown in the Table9. 
Table 9 - Results of calculations the private immanent components of qualitative measurement that influence online retailers' MSMCP

\begin{tabular}{|r|c|c|c|c|c|c|c|}
\hline Online retailer & $\boldsymbol{F R 1}$ & $\boldsymbol{F R 2}$ & $\boldsymbol{F R 4}$ & $\boldsymbol{D R 1}$ & $\boldsymbol{D R 2}$ & $\boldsymbol{H A 1}$ & $\boldsymbol{H A 2}$ \\
\hline$Z_{P R}$ & 3.733 & 4.022 & 3.553 & 3.282 & 3.388 & 4.031 & 3.361 \\
\hline$Z_{O I}$ & 5.315 & 5.315 & 3.764 & 3.898 & 4.606 & 5.315 & 4.606 \\
\hline$Z_{P R}$ & 2.638 & 3.720 & 4.211 & 3.584 & 3.129 & 2.552 & 2.168 \\
\hline$Z_{O I}$ & 3.677 & 4.961 & 4.827 & 4.606 & 4.606 & 3.764 & 3.409 \\
\hline Online retailer & $\boldsymbol{H A 3}$ & $\boldsymbol{H A 4}$ & $\boldsymbol{H A 5}$ & $\boldsymbol{H A 6}$ & $\boldsymbol{D I Y 5}$ & $\boldsymbol{F R 3}$ & $\boldsymbol{F R 5}$ \\
\hline$Z_{P R}$ & 3.106 & 3.782 & 3.766 & 4.088 & 4.169 & 3.194 & 3.423 \\
\hline$Z_{O I}$ & 4.338 & 4.559 & 5.181 & 4.693 & 5.315 & 4.338 & 4.300 \\
\hline
\end{tabular}

Source: composed by the author

According to the results of the calculations, three groups of online retailers were identified, depending on the influence of private immanent quality measurement components on online retailers' MSMCP. For this purpose, taking into account the minimum and maximum value of impact assessment, three rating intervals were determined (Table 10).

Table 10 - Intervals for assessments

\begin{tabular}{|l|c|c|}
\hline \multicolumn{1}{|c|}{ Influence } & $Z_{P R}$ & $Z_{O I}$ \\
\hline Low (1) & $2.168 \leq Z_{P R}<2.849$ & $3.410 \leq Z_{O I}<4.045$ \\
\hline Average (a) & $2.849 \leq Z_{P R}<3.530$ & $4.045 \leq Z_{O I}<4.680$ \\
\hline High (h) & $3.530 \leq Z_{P R} \leq 4.211$ & $4.680 \leq Z_{O I} \leq 5.315$ \\
\hline
\end{tabular}

Source: developed by the author

The Table 11 reflects the summarized results of dividing online retailers into three groups depending on the assessments.

Table 11 - The assessments of the private immanent components of qualitative measurement that influence online retailers' MSMCP

\begin{tabular}{|r|c|c|c|c|c|c|c|}
\hline Online retailer & $\boldsymbol{F R 1}$ & $\boldsymbol{F R 2}$ & $\boldsymbol{F R 4}$ & $\boldsymbol{D R 1}$ & $\boldsymbol{D R 2}$ & $\boldsymbol{H A 1}$ & $\boldsymbol{H A 2}$ \\
\hline$Z_{P R}$ & $\mathrm{~h}$ & $\mathrm{~h}$ & $\mathrm{~h}$ & $\mathrm{a}$ & $\mathrm{a}$ & $\mathrm{h}$ & $\mathrm{a}$ \\
\hline$Z_{O I}$ & $\mathrm{~h}$ & $\mathrm{~h}$ & 1 & 1 & $\mathrm{a}$ & $\mathrm{h}$ & $\mathrm{a}$ \\
\hline$Z_{P R}$ & 1 & $\mathrm{~h}$ & $\mathrm{~h}$ & $\mathrm{~h}$ & $\mathrm{a}$ & 1 & 1 \\
\hline$Z_{O I}$ & 1 & $\mathrm{~h}$ & $\mathrm{~h}$ & $\mathrm{a}$ & $\mathrm{a}$ & 1 & 1 \\
\hline
\end{tabular}


Tabl. 11 continued

\begin{tabular}{|r|c|c|c|c|c|c|c|}
\hline Online retailer & FR6 & DIY3 & DIY1 & DIY2 & DIY4 & DIY6 & DIY7 \\
\hline$Z_{P R}$ & $\mathrm{a}$ & $\mathrm{h}$ & $\mathrm{h}$ & $\mathrm{h}$ & $\mathrm{h}$ & $\mathrm{a}$ & $\mathrm{a}$ \\
\hline$Z_{O I}$ & $\mathrm{a}$ & $\mathrm{a}$ & $\mathrm{h}$ & $\mathrm{h}$ & $\mathrm{h}$ & $\mathrm{a}$ & $\mathrm{a}$ \\
\hline
\end{tabular}

Source: developed by the author

Conclusions from this research and prospects for further developments in this area. The results of the calculations indicate that online retailers of group 1 with a low assessment of the influence of private immanent quality measurement components on online retailers' MSMCP, do not fully take into account the influence of latent root causes (product range competitiveness, interaction with online shoppers). This leads to online retailers conducting a detailed analysis of the product portfolio and identifying reserves for its renewal or differentiation; increasing the loyalty of online shoppers, in particular, increasing the number of marketing communication Internet channels and marketing instruments with online shoppers for communicating with them before and after online sales. Online retailers of groups 2 and 3 have, respectively, medium and high rates for the influence of private immanent quality measurement components on online retailers' MSMCP. For online retailers with an average impact assessment, it is advisable to implement appropriate marketing efforts for increasing degree of integration with the product category management system; market development strategy; try to maximize the ever-changing individual needs of online shoppers. For online retailers of group 3, it is advisable to follow the chosen action vector in the framework of the marketing commodity policy.

1. All Retail. (2018). Retrieved from http://allretail.ua.

2. Bharadwaj, A., El Sawy, O., Pavlou, P., \& Venkatraman, N. (2013). Digital business strategy: toward a next generation of insights. MIS Quarterly, 37 (2), 471-482.

3. Deloitte. (2018). Retail Trends 2018. Retrieved from: https://www2.deloitte.com/content/dam/Deloitte/uk/Documents/consumer-business/deloitte-uk-retailtrends-2018.pdf.

4. Demo version of the software package "SPSS Statistics". www.ibm.com Retrieved from: https://www.ibm.com/products/spss-statistics.

5. Demo version of the software package "STATISTICA". statfort.ru Retrieved from: http://statsoft.ru/products.

6. GfK Ukraine. (2018). Retrieved from http://www.gfk.com/uk-ua.

7. Kane, G., Palmer, D., Philips Nguyen, A., Kiron, D. \& Buckley, N. (2015). Strategy, Not Technology, Drives Digital Transformation. MIT and Deloitte. Retrieved from: http://sloanreview.mit.edu/projects/strategy-drives-digital-transformation/.

8. KPMG. (2018). Global retail trends. Retrieved from: https://assets.kpmg.com/content/dam/kpmg/xx/pdf/2018/03/global-retail-trends-2018.pdf.

9. Matskul, V.M. (Eds.). (2016). Matematychni metody ta modeli v ekonomichnykh doslidzhenniakh: monohrafiia [Mathematical methods and models in economic research: monograph]. Odesa: ONEU, 184 [in Ukrainian].

10. MIT Center for Digital Business. (2018). www.ebusiness.mit.edu Retrieved from: http://ebusiness.mit.edu/research/index.html.

11. Oklander, M.A., Oklander, T.O., \& Yashkina, O.I. (2017). Tsyfrovyi marketynh - model marketynhu XXI storichchia [Digital Marketing - The Marketing Model of the 21st Century]. Oklander, M.A. (Ed.). Odesa [in Ukrainian]. 
12. Prom.ua. (2017). Retrieved from: https://prom.ua.

13. Reevoo. (2018). Retrieved from: https://www.reevoo.com.

14. The World Economic Forum (2018). Retrieved from: https://www.weforum.org.

15. Ukrainian Retail Association (2018). Retrieved from: https://rau.ua/uk.

A.О. Наторіна, канд. екон. наук, начальник відділу статистики $і$ аналітики вищої освіти, ДНУ «Інститут освітньої аналітики» (Київ, Україна).

Квалітативна оцінка маркетингових чинників впливу на цифровий бізнес.

Систематизовано частинні іманентні компоненти впливу на систему управління маркетинговою товарною політикою (СУМТП) онлайн-ритейлерів якісного вимірювання та розроблено відповідну їх архітектоніку. Ідентифіковано латентні першопричини формування СУМТП онлайн-ритейлерів, ще детермінують частинні іманентні компоненти впливу якісного вимірювання, а також пояснюють кореляцію між відповідними ознаками та змістовно їх інтерпретують. Розроблено канонічні моделі оцінки частинних іманентних компонентів впливу на СУМТП онлайн-ритейлерів, реалізаџія яких $є$ фундаментом для генерування дієвих маркетингових рішень та досягнення відповідних иілей за рахунок точкового управлінського впливу. Обтрунтовано методичний підхід до квалітативної очінки маркетингових чинників, щэо впливають на цифровий бізнес. Розроблено пропозииї та рекомендації для онлайн-ритейлерів за результатами апробаиії і валідації методичного підходу.

Ключові слова: цифровий бізнес, онлайн-ритейлер, система управління маркетинговою товарною політикою, іманентний компонент, канонічна модель.

Received to the editor February 25, 2019. 